\title{
Strategy to Realize E-Government As The Public Transparency to Preventive Government of Corruption
}

\author{
$1^{\text {st }}$ Irawati $^{1}, 2^{\text {nd }}$ Syahrul Reza ${ }^{2}$ \\ \{irawati@stiami.ac.id ${ }^{1}$, ukhti.ra@gmail.com ${ }^{1}$,ts.reza@stiami.ac.id ${ }^{2}$ \} \\ Institut Ilmu Sosial dan Manajemen STIAMI ${ }^{1}$, Mandala International Education Institute STIAMI \\ Jakarta $^{2}$
}

\begin{abstract}
Efforts to prevent opportunities for corruption can rationally be carried out and constitute a preventive effort by implementing e-government which utilizes online-based computerized technology. An integrated system is needed so that e-government implementation can be directly connected from each region to the center. This is necessary in reviewing the development of regional capacities in managing their regions, the condition of their fiscal decentralization management capabilities and reducing corruption related to regional finances. The Central Government makes it easier to balance regional welfare in this case the distribution of the General Allocation Fund (DAU). There needs to be a central policy that provides awards, so that regions that are already independent, regional heads are proud to pay their own employees, without expecting general allocation funds from the central government. Fiscal effectiveness or fiscal decentralization can be realized if the government implements integration that promotes welfare. By increasing the Human Development Index (HDI) and maintaining market prices so that there is no monopoly that hinders public consumption. The consideration is that the high level of human development or showing the development of developing regions will automatically increase tax revenue. Research suggests that the government needs to make policies that are conducive to tax effectiveness.
\end{abstract}

Keywords: E-Government, Transparency, Corruption.

\section{Introduction}

Organizing Public Services is one of the important functions of the government. This function is the real actualization of the social contract given by the community to the government in a Principal-agent relationship (Rawls, 1971) in Tarigan (2003). Efforts to improve the quality of public services at all levels of government with the Law of the Republic of Indonesia Number 25 of 2009 concerning Public Services, and Regulation of the Minister of State for Administrative Reform and Bureaucratic Reform of the Republic of Indonesia Number 7 of 2010 concerning Guidelines for Evaluating Public Service Performance.

The phenomenon of malpractices has become an integral part of organizing public services in Indonesia. This can be traced from the number of complaints made by the community regarding the poor performance of public services in Indonesia. This is traced to the number of complaints made by the community regarding the poor performance of the 
bureaucracy. Long-term service, high fees, additional fees, the behaviour of officials who act more as officials than public servants and discriminatory services (Tarigan, 2003)

The smooth implementation of general tasks of government and development depends on the behaviour of bureaucrats as Civil Servants. To achieve a just development goal, realizing a law-abiding civil society that is modern, democratic, prosperous and highly moral is needed for bureaucrats who serve as public servants fairly, efficiently and effectively. And being a general fact in the bureaucratic scope, the implementation of poorly planned activities results in overlapping, lack of coordination, communication between implementers is less effective, lack of motivation, lack of transparency, lack of accuracy, lack of understanding of tasks and mutual responsibility. The community as the subject of service no longer likes the process of public service is complicated, long, and risky because of the long chain of bureaucracy.

Wahyudi Kumorotomo ( 2005) quotes the Parkinson Theory as saying that within each formal structure there is a tendency for increasing personnel in organizational units. Every time he gets an assignment, officials will generally form new bureaucratic units or recruit new people. This resulted in a swelling of the bureaucracy both in terms of the number of units and the number of employees. Because the land and income sources that can be extracted by employees become more limited, they are finally encouraged to commit acts of corruption. Of course, this is not the only reason that employees commit corruption.

According to Ivancevich, Lorenzi, Skinner and Crosby (Ratminto and Atik Septi Winarsih, 2010: 2) " service is visible products (cannot be touched) that involve human efforts and use of equipment ". Organizational, management, political and administrative science that deals with how to achieve output or objectives efficiently and effectively. To achieve Efficient and Effective equipment is needed because the millennium era is the era of computer technology that is based on internet access that can provide information quickly, EGovernment is a tool that cannot be negotiated if Indonesia wants equitable development in all fields. Theoretically, the government can improve the performance of quality public services, this is because all creativity has been given to the government to carry out public services in the context of public welfare. However, in the course of the wheels of government many experienced obstacles or obstacles, for example, the budget allocated by the government in the framework of public services is still very limited, the mindset of bureaucrats tends to place itself as an agent of power rather than a service agent. These conditions that make the future of people's lives will be bleak because people are very dependent on the services provided by the government.

Efforts to realize quality public services can be done by civilizing the concept of public accountability basically, government institutions are actually created and held by the public (Hughes, 1994) in (Prianto, 2006: 122), on the basis of the theory above bureaucrats in government institutions must be accountable for their performance to the public, covering all behaviors, attitudes of work actions and various decisions made in order to carry out their duties and obligations

Their actions were in violation, such as corruption needs to be anticipated prevention (preventive) systematically, so that there are no opportunities for corruption. But what kind of system model that makes corruption is no chance? For this reason, this article was made. 


\section{Literature Review}

\subsection{E-Government In Indonesia}

The definition of E-Government by the World Bank (The World Bank Group, 2001): Egovernment refers to the use by government agencies of information technologies (such as Wide Area Network, the internet, and mobile computing) that have the ability to transform relations with citizens, business, and other arms of government.

The implementation of E-Government has a legal basis since the existence of Presidential Instruction N0.3 of 2003 which is a legal umbrella for developing e-government. This can encourage local governments to make a technical legal umbrella in the form of a Governor's Decree or Decree of the Regent / Mayor. So those e-government activities are not hampered by budget allocations. Then with the policy of Presidential Regulation No. 96 of 2014 concerning the Indonesia Broadband Plan for 2014-2019 in order to realize an independent, developed, fair and prosperous Indonesian society which is the vision of the 2005-2025 National Long Term Development Plan and one of the manifestations of the implementation of the 2011 Indonesian Economic Development Acceleration and Expansion - 2025, it is necessary to use information and communication technology, especially broadband (broadband) as an inseparable part of the strategy, to encourage economic growth and national competitiveness, and improve the quality of life for the people of Indonesia. Presidential Regulation No. 96 of 2014 concerning broadband plans, namely: procurement: 1). EGovernment, 2). E-Health, 3) E-Education, 4) E-Logistics and 5). E-Procurement.

So far some examples of the implementation of E-Government in Indonesia are:

1. E-procurement is the procurement of electronic development tenders so that potential flirting between providers and users of goods/services can be prevented.

2. Licensing on line, also known as the One-Stop Integrated Service (PTSP) to cut the bureaucracy and facilitate investment

3. (LARASITA) for making land certificates

4. (SIAK) or population administration information system

5. SMS centre for the event of interaction between the government and the community. Can be truant civil servant complaints, the latest issues

6. and ect.

The development of e-government applications requires substantial funding so that readiness from the human, government apparatus and readiness of the community is needed. The unpreparedness of human resources, organizational culture, facilities and infrastructure of information technology (infrastructure), and the lack of attention from parties directly involved can be the cause of failure in implementing e-government. However, one of the issues that are currently developing related to the implementation of e-government in Indonesia is the lack of optimal Information Technology (IT) products in the government environment and the lack of synergy implementation of e-government (Safitri Jaya: 2013)

Safitri Jaya: 2013 explained several weaknesses in the formation of e-government in Indonesia:

1. Services provided by government sites have not been supported by an effective management system and work processes because preparedness of regulations, procedures and human resource limitations severely limits computerized penetration into the government system.

2. The strategy has not been established and the inadequacy of the budget allocated for the development of e-government. 
3. The initiative is an agency effort individually, so several factors such as standardization, information security, authentication and various basic applications that allow interoperability between sites reliably, safely, and reliably receive less attention.

4. Gaps in people's ability to access the internet network.

According to Arief Budi Pratama (2005) E-government logically can act as a prevention of corruption because: First, the implementation of e-government in the administration of government such as in Public Services, Public Policy, will further minimize direct contact between actors so that deviations can be reduced.

Second, with the implementation of e-government, more transparency will be created where each party can know important data or information needed by stakeholders. The level of data manipulation can be more easily tracked to find out the actual data. For example, STNK / SIM extension via the internet with the type of transaction will be easier for users/users because in the access channel Samsat extension of SIM and STNK has clear and transparent information so that it will close the possibility of the role of brokers in it.

With the implementation of e-government, the performance of public organizations will be more efficient, effective, transparent, accountable, creative, and participatory. The concept of e-Government does not only mean that there is a good change in performance from the government to its people but further means that there is a transformation in the approach of administering a government from a government-centred (executive) to a community-centred (democracy).

The slow pace of evolution of a country from the Knowledge Society towards eGovernment is very dependent on how sensitive the government and its people are in reading the signs of the times (trends or trends).

In this era of globalization, there are very many variables and parameters that are outside the control of a country concerned, so there is no way another is that if you want to stay in the world community, the government and society of a country must have a sharp and accurate strategy. This is also the reason why so many third world countries and underdeveloped countries have begun to think about and carry out planning, development, and development of the concept of e-Government in their respective countries. This is because they are aware that e-Government does not only have internal boundaries (only applies and is beneficial to society in a country), but can actually be a reliable facility and medium in its efforts to establish bilateral and multilateral cooperation with other countries (Indrajit, 2002).

\subsection{Corruption Description In Indonesia}

Based on the evaluation report on the prevention and eradication of corruption issued by the Ministry of PPN / Bapennas in 2010 FROM 2006-2010 the perception index of corruption in Indonesia experienced a positive increase. This shows that prevention efforts by the government are quite good. As illustrated in table 1 below.

Table 1. Corruption Perception Index in Indonesia

\begin{tabular}{|l|l|}
\hline Tahun & Skor \\
\hline $\mathbf{2 0 0 6}$ & 2,4 \\
\hline $\mathbf{2 0 0 7}$ & 2,3 \\
\hline $\mathbf{2 0 0 8}$ & 2,6 \\
\hline $\mathbf{2 0 0 9}$ & 2,8 \\
\hline $\mathbf{2 0 1 0}$ & 2,8 \\
\hline
\end{tabular}


Evaluasi laporan pada tahun 2010 pemberantasan korupsi di Indonesia mendapat tantangan yang besar. Hal ini dapat dilihat dari Indeks Persepsi Korupsi Indonesia sebesar 2,8 yang tidak berubah dari skor pada tahun 2009. Indonesia berada satu kelas dengan negara-negara seperti Benin, Bolivia, Gabon, Kosovo dan Solomon Islands yang sama- sama mempunyai skor 2,8 dan berada pada urutan 110. Di tingkat negara-negara ASEAN, Indonesia berada di bawah Singapura, Brunei, Malaysia, Thailand, tetapi masih lebih baik dari Vietnam, Filipina, Kamboja, Laos dan Myanmar.

Table 2 ASEAN Country Corruption Perception Index

\begin{tabular}{|cc|}
\hline Negara & Skor CPI 2010 \\
\hline Singapura & 9,3 \\
\hline Brunei Darussalam & 5,5 \\
\hline Malaysia & 4,4 \\
\hline Thailand & 3,5 \\
\hline Indonesia & 2,8 \\
\hline Vietnam & 2,7 \\
\hline Timor Leste & 2,5 \\
\hline Filipina & 2,4 \\
\hline Kamboja & 2,1 \\
\hline Myanmar & 1,4 \\
\hline
\end{tabular}

Source:International Transparancy

The biggest corruption sector case in 2010 based on ICW data (Indonesia Corruption Watch) is the regional financial sector with Rp. 596.232 billion (38 cases), Licensing Rp. 420 billion ( 1 case), Mining Rp. 365.5 billion ( 2 cases), Energy/electricity of IDR 140.8 billion ( 5 cases), and Banking IDR 96.1 billion ( 3 cases). While the Data mode from ICW shows the biggest mode of corruption revealed during the first semester of 2010 was the mode of embezzlement with 62 cases, followed by the markup mode of 52 cases, fictitious projects of 20 cases, misuse of the budget of 18 cases and bribes of 7 cases.

\section{Discussion}

To realize effective e-government needs resources or quality resources, among others, is the first preparation of funds to create a systematic and integrated e-government system with stakeholders both government in ministries and central government institutions so that good servers are needed, both human resources who are competent in operating the software, so the task of bureaucrats as public administrators can be carried out, namely as a public service that functions optimally.

E-Government that is built needs to be made an integrated or integrated system model that includes several stages,

1. How to choose the target is;

2. Setting goals,

3. Validating Goals,

4. Realizing the Target,

5. Controlling the target. 
If viewed from the stages of implementation of e-government above is a form of control of planning performance or planning performance of government tasks. Those connected to the internet in each government stakeholder division. With connected planning, e-government will be easier to control or control so that goal is achieved effectively.

\section{Conclusion}

1. Creating e-government is an activity that cannot be negotiated by the Indonesian government because the millennium era demands online-based computer technology to accelerate access to information.

2. The implementation of e-government in Indonesia faces many problems, among others, the lack of preparedness of funds in developing such systems in areas that have not been established, related to the unavailability of resources. And the lack of support from relevant agencies and the power of regional leaders in realizing their regional vision of the strategy (thinking long-term goals) is not just thinking about carrying out missions (short term)

3. Because the e-government system model is an integrated or integrated model, the system model is the basis for making planning software or planning implications for the implementation of e-government. Consists of: How to choose a target or goal; Setting goals; Validating goals; Realizing the final goal and controlling the target example: preparation of the mechanism/procedure performance from the process of input to output if the service is from the queue number to the process until the output of goods and services is issued.

4. E-Government is a form of realizing transparency of public information, the impact of which can prevent corruption as a preventive effort, and in the context of realizing Good Governance towards a civil society.

\section{Recommendation}

1. An integrated or integrated system model is needed in the implementation of egovernment connected from regions to central government or government stakeholders (stakeholders)

2. The Head of State as head of government must think strategically towards egovernment up to the regions, therefore the central government also needs to think about allocating funds in building e-government systems in the regions as a form of corruption prevention in regional finance based on 2010 research the most done by ICW (index Corruption Watch).

3. There needs to be a government policy in the form of rewards or awards not only in the form of trophies or plaques but prizes can be additional remuneration or grand (grants) if for each regional head to realize effective e-government innovations, so the impact is progress and independence in regional development and the welfare of the community.

4. There is a strict law for bureaucrats who commit corruption with severe penalties, in accordance with the corruption committed, so that it builds the shock of Terapy, for government bureaucrats who are proven to commit corruption. 


\section{References}

[1]. Indrajit, Richardus Eko. 2004. Electronic Government: Strategi Pembangunan dan Pengembangan Sistem Pelayanan Publik Berbasis Teknologi Digital. Yogyakarta: ANDI.

[2]. Kumorotomo, Wahyudi. 2005. Pelayanan akuntabel dan bebas dari KKN dalam buku Mewujudkan Good Governance Melalui Pelayanan Publik. Yogyakarta: Gajah Mada University Press

[3]. Matti Malkia, Ari-Veiko Anttiroiko and Reijo Savolainen, -eTransformation in Governance New Directions in Government and Politics II, Idea Group Publishing, 2004

[4]. Nugroho, Riant. 2003. Kebijakan Publik-formulasi, Implementasi, dan evaluasi. Jakarta: Gramedia

[5]. Pratama, Arief Budi. 2005. Implementasi E-Government dalam Penyelenggaraan Pemerintah. "Dialogue" JIAKP, Vol. 2, No. 3, September 2005 : 939-960

[6]. Pusat Pengembangan Informatika Nuklir - Batan "Kebijakan dan Strategi Pengembangan egovernment" www.batan.go.id/sjk/e-gov.html, Januari 2011

[7]. S. Jaya. Implementasi dan Perkembangan E-Government di Indonesia. 2013. Jurnal Informatika Media. Makasar : Stimed Nusa Palapa Makasar

[8]. United Nation, 2008. United Nations e-government Survey 2008 : From e- government to connected governance. New York: United Nations.http://unpan1.un.org/intradoc/groups/ public/documents/UN/UNPAN028607. Pdf

[9]. Yuwono, Teguh. 2001. Manajemen Otonomi Daerah. Semarang: Gloggaps.

[10]. World Bank, e-government for all - Review of International Experience with Enhancing public Access, Deman 